confined to his home for several months prior to his death. He had never married and is survived by his sister, Miss Elizabeth Downs. He had been a valued member of the Business Historical Society since 1927 and his passing constitutes a personal loss for many members and friends of the Society.

\title{
Daniel G. Wing
}

Just as the Bulletin was going to the printer, the Society received the sad news of the death of Daniel Gould Wing at his home in Brookline, Massachusetts, on January 27, 1936. Long a respected and admired leader in New England banking, Mr. Wing had, in September, 1935, resigned his position as chairman of the board of directors of the First National Bank of Boston on account of the ill health which had troubled him for many months.

Mr. Wing was born in Davenport, Iowa, September 10, I 868, and began his banking career in 1885 as a messenger for the State National Bank, Lincoln, Nebraska. Working up rapidly, he soon became cashier of the American Exchange National Bank of Lincoln, which he left in 1897 to become a national bank examiner. In this capacity he came to Boston in 1899 and was made receiver of the Globe National Bank and Broadway National Bank. Within only a few months he had shown such marked capacity that he was made a vice-president and director of the Massachusetts National Bank. Its president, John W. Weeks, was anxious to devote full attention to his own firm of Hornblower \& Weeks, and before the end of I goo Mr. Wing was really the manager of the Massachusetts National, though he was not formally made president until 1903. When the Massachusetts National merged with the First National, later in 1903, he was made president of the First National Bank. He continued to hold this position until I 926, when he was elected chairman of the board. In addition he was a director and member of the executive committee of other corporations, including the Pacific Mills, United Fruit Company, United Shoe Machinery, New England Power Association, and the United States Smelting, Refining and Mining Company. He had been a member of the Business Historical Society since 1927 .

Those who knew him will heartily concur in the following statement from an editorial which the Boston Evening Transcript published on Mr. Wing: "By his constructive powers he led this institu- 
tion to a place as the largest bank in New England and one of the principal banks of the United States. He deserves and will be given memory as one of the most significant citizens of Boston in modern times."

\section{BOOK NOTICES}

Anne Bezanson, Robert D. Gray, Miriam Hussey, Prices in Colonial Pennsyl vania. Research Studies of the Industrial Research Department, Wharton School of Finance and Commerce, XXVI. Philadelphia: University of Pennsylvania Press, r 935. Pp. xix, 445. \$4.0o. A detailed study of prices in Pennsylvania between 1720 and 1775 , with additional data to aid in interpreting the fluctuations. Prices of staple agricultural commodities; staves; naval stores; pig and bar iron; sugar, molasses, rum, and other West Indian products; staple imports from Europe; British goods; general index of prices; sterling exchange. Appéndix on methods used. Numerous tables, 33 charts, and bibliography.

Herbert Heaton, Economic History of Europe. New York: Harper \& Brothers, 1936. Pp. xiv, 775. \$3.50. An eminently readable history which is notable for the attention given to business developments. Embodies a great deal of recently published material, including articles in the Journal of Economic and Business History. Bibliographies at the end of the chapters.

Samuel McKee, Jr., Labor in Colonial New York, $1664-1776$. Columbia Studies in History, Economics, and Public Law, no. 410 . New York: Columbia University Press, 1935. Pp. 193. \$3.00. A study of free, apprenticed, indentured, and slave labor. Since no space is devoted to working conditions, except to indicate abuses, the book does not fully succeed in its purpose of setting forth "the theoretical and actual position of labor." It is also marred by the author's mistaken belief that the gild system was working well in seventeenth and eighteenth century Europe. Good on legal position of labor which is the real subject of the book. Bibliography.

Heinrich Sieveking, Wirtschaftsgeschichte. Enzyklopädie der Rechts- und Staatswissenschaft, no. XLVII. Berlin: Verlag von Julius Springer, I 935. Pp. vii, 209. RM I 3.80. A concise and comprehensive survey of the economic history of the Western World from ancient times to 1935 , with an emphasis upon the development of capitalism. Bibliographies at the end of each section.

\section{Secretary's Column}

The Secretary is happy to be able to report that the Society has acquired a number of new members during the past six months, as follows:

\section{General Members}

William C. Dickerman, President, American Locomotive Co., New York City Sidney Homer, Jr., President, Homer \& Co., New York City 